\title{
Development and production of sugarcane under different levels straw after four years of cultivation
}

\section{Desenvolvimento e produção de cana-de-açúcar sob diferentes quantidades de palhada após quatro anos de cultivo}

\author{
Gisele Silva de Aquino ${ }^{1 *}$; Cristiane de Conti Medina ${ }^{1}$; \\ Ana Carolina Benitez Cunha²; Deise Akemi Omori Kussaba²; \\ Jaime Higino dos Santos Junior²; Jéssica Barbieri Carvalho ${ }^{3}$; Adônis Moreira ${ }^{4}$
}

\begin{abstract}
Environmental constraints, labour shortages and the search for greater efficiency have induced the mechanisation of sugarcane harvesting, providing a large amount of straw in the system, which provides benefits to the soil, the crop and the environment. The objective of this work was to evaluate the effect of the removal of different amounts of straw from the soil surface on the development and productivity of sugarcane in eutrophic Red Latosol. The experiment was conducted in an area belonging to the Usina in Bandeirantes, PR, using a randomised block design with four replications. The effects of six treatments $(0,25 \%, 50 \%, 75 \%, 100 \%$ of straw and sugarcane) were evaluated after four years of cultivation on the LAI (leaf area index), tillering, diameter, length and fresh mass of the stalks, in five periods: 60, 120, 180, 240 and 370 days after harvest (DAC). The results were submitted to analysis of variance and the means compared by Tukey's test. The straw on the soil surface provided benefits to the development and productivity of sugarcane. The management of sugarcane burning, total removal of the straw $(0 \%$ of soil cover) or $75 \%$ of straw resulted in a lower IAF and stalk diameter and a $37 \%$ decrease in final yield under conditions of water deficiency. The maintenance of $50 \%$ of straw is sufficient to favour the development and to provide greater productivity of the sugarcane, as it is possible to use the $50 \%$ surplus of the field for the production of ethanol of second generation or electric energy, without damage to the productivity of the culture.
\end{abstract}

Key words: Straw sugarcane. Ground cover. Biometry. Biomass.

\section{Resumo}

As restrições ambientais, a falta de mão-de-obra e a busca por maior eficiência induzem a mecanização da colheita de cana-de-açúcar, disponibilizando grande quantidade de palhada no sistema, que proporciona benefícios ao solo, à cultura e ao meio ambiente. O objetivo desse trabalho foi avaliar o efeito da retirada de diferentes quantidades de palhada da superfície do solo sobre o desenvolvimento e a produtividade da cana-de-açúcar em Latossolo Vermelho eutroférrico. O experimento foi instalado em área pertencente a Usina em Bandeirantes, PR, utilizando delineamento em blocos casualizados com quatro repetições.

\footnotetext{
${ }^{1}$ Prof $^{\text {as }} \operatorname{Dr}^{\text {as }}$, Departamento de Agronomia da Universidade Estadual de Londrina, UEL, Londrina, PR, Brasil. E-mail: gisele.s.aquino@hotmail.com; medina@uel.br

2 Discentes, Curso de Agronomia, Departamento de Agronomia, UEL, Londrina, PR, Brasil. E-mail: anabenitez51@gmail.com; deise.akeemi@hotmail; junior_higino@hotmail.com

3 Discente de Mestrado do Programa de Pós-graduação em Bioenergia, UEL, Londrina, PR, Brasil. E-mail: je_barbieri_carvalho@ hotmail.com

4 Pesquisador, Departamento de Ciência de solo da Empresa Brasileira de Pesquisa Agropecuária, EMBRAPA, Londrina, PR, Brasil. E-mail: adonismoreira66@gmail.com

* Auhtor for correspondence
} 
Foram avaliados os efeitos de seis tratamentos $(0,25 \%, 50 \%, 75 \%, 100 \%$ de palhada e cana-queimada), após quatro anos de cultivo, sobre o IAF (Índice de área foliar), perfilhamento, diâmetro, comprimento médio e massa fresca dos colmos, em cinco períodos: 60, 120, 180, 240 e 370 dias após a colheita (DAC). Os resultados foram submetidos à análise de variância e as médias comparadas pelo teste Tukey. A palhada sobre a superfície do solo proporcionou benefícios ao desenvolvimento e a produtividade da cana-de-açúcar. Os manejos queima da cana-de-açúcar, retirada total da palhada ( $0 \%$ de cobertura do solo) ou de $75 \%$ de palhada resultaram em menor índice de área foliar, diâmetro de colmos e diminuição de $37 \%$ na produtividade final, em condições de deficiência hídrica. A manutenção de 50\% de palhada é suficiente para favorecer o desenvolvimento e proporcionar maior produtividade da cana-de-açúcar, sendo possível utilizar os $50 \%$ excedente do campo para produção de etanol de segunda geração ou energia elétrica, sem prejuízos à produtividade da cultura.

Palavras-chave: Palhiço de cana-de-açúcar. Cobertura do solo. Biometria. Biomassa.

\section{Introduction}

The mechanised harvesting system, which has been adopted recently by the main sugarcane producing areas in Brazil (POTRICH et al., 2014) leaves between 10 and $30 \mathrm{Mg} \mathrm{ha}^{-1}$ of dry matter of vegetal residue - straw - on the soil surface (OLIVEIRA et al., 2003). The straw is composed of dried leaves, pointers and green leaves that are cut and thrown on the surface of the soil. More than 140 million tons of straw are generated annually (UNICA, 2015).

This layer of plant material on the soil causes changes in the production environment that directly interfere with budding, emergence and plant development. This fact becomes more important when we consider that the currently available sugarcane varieties were genetically developed in the harvesting system with burning (SOUZA et al., 2005). Thus, studies need to identify the behaviour of the plant in this new system and the correct management to be applied in this new cultivation reality.

The main changes caused by straw on the soil surface are the following: greater efficiency in the control of erosion and increase of the organic matter content, macro and microfauna, improving the soil structure, alteration in the incidence of light on the surface; increased infiltration of water into the soil; decrease in thermal amplitude and evaporation, especially in the superficial layers (INMANBAMBER; SMITH, 2004; GARCIA et al., 2007;
CHRISTOFFOLETI et al., 2007; CAVENAGHI et al., 2007; GUIMARÃES et al., 2008; TAVARES et al., 2010; COSTA et al., 2014; PAREDES JUNIOR et al., 2015; VALIM et al., 2016).

The influence of straw in tillering, fresh biomass accumulation and productivity of sugarcane variety strains SP 832847 was evaluated by Campos et al. (2008). They observed negative effects of straw in total area with the three variables, with reduction of about $10 \%$ in productivity. Similar results were found by Campos et al. (2010), who evaluated the effects of $10 \mathrm{t} \mathrm{ha}^{-1}$ of straw, in the second ratoon variety RB 855453 in Red Oxisol Eutrophic. However, Ball Coelho et al. (1993) observed that the maintenance of the straw on the soil (Argisol oxico) caused increases of $43 \%$ in the dry matter production of the first sugarcane ratoon. Resende et al. (2006) also reported the benefits obtained with the maintenance of straw on the soil surface after 16 years of cultivation. However, the studies described in the literature do not address the amount of straw that would be sufficient to obtain such benefits or the effect of maintaining smaller amounts on the crop.

The straw represents approximately one-third of the total primary energy of sugarcane. For this reason, there is an increasing interest in the use of straw left in the field that can be recovered and used in the generation of surplus electricity, the production of cellulosic ethanol and/or solid fuels (pellets and briquettes). It is estimated that the use of straw along with bagasse would triple the country's 
ethanol production without the need for an increase in the planting area (LIMA; NATALENSE, 2010) or would produce the equivalent of $15 \%$ of the total energy consumed in Brazil until 2020 (CEISE, 2016).

However, not all straw can be removed, as part of it should remain on the ground to avoid changes that compromise the sustainability of the production system. If, on the one hand, removal of the straw can generate additional profit for the mills, on the other hand, its maintenance plays an important role in the conservation of soil and water, avoiding erosion and water losses that lead to the disintegration and dragging of the fertile soil.

In this way, it is understood that work is primordial that identifies the amount of straw needed to remain in the field for greater benefit of the crop and sustainability of the soil system, which could be removed without damage to the crop.

The objective of this work was to evaluate the effect of the removal of different amounts of straw from the soil surface on the development and yield of sugarcane ratoon after four years of cultivation in Eutrophic Red Latosol.

\section{Material and Methods}

The experiment was conducted in the city of Bandeirantes, in an area belonging to the Açúcar and Álcool Bandeirantes Plant, located at latitude $23^{\circ} 06^{\prime} \mathrm{S}$, longitude $50^{\circ} 21^{\prime} \mathrm{W}$ and altitude of 440 $\mathrm{m}$, in an eutrophic Red Latosol (EMBRAPA, 2013), with the following physical and chemical attributes in the layer: 0-0.20 m (EMBRAPA, 1997): 61\% clay; $2 \%$ silt and $37 \%$ sand, OM $\left(\mathrm{g} \mathrm{kg}^{-1}\right) 34.2 ; \mathrm{P}$ (mg dm${ }^{-3}$ - extractor Melich) 39.9; $\mathrm{K}\left(\mathrm{Cmolc} \mathrm{dm}^{-3}\right)$
3.0; $\mathrm{Ca}\left(\mathrm{Cmolc} \mathrm{dm}{ }^{-3}\right) 7.8 ; \mathrm{Mg}\left(\right.$ Cmolc dm$\left.^{-3}\right)$ 1.8; $\mathrm{H}+\mathrm{Al}\left(\mathrm{Cmolc} \mathrm{dm}{ }^{-3}\right)$ 3.0; CEC $\left(\right.$ Cmolc dm $\left.\mathrm{dm}^{-3}\right)$ 15.7; $\mathrm{pH}\left(\mathrm{CaCl}_{2}\right) 5.6$ and $\mathrm{V}(\%) 80.8$.

The predominant climate in the region, based on the Koeppen climate classification, is the Cfa type, with an annual average precipitation of 1,300 $\mathrm{mm}$. The average annual insolation is $7.14 \mathrm{~h}^{-}$day $^{-}$ 1. The climatological water balance (Figure 1) was calculated according to Thornthwaite and Mather (1955). The average monthly temperature data and total monthly rainfall were provided by the meteorological station of the Agronomic Institute of Paraná (IAPAR), located $2 \mathrm{~km}$ from the experiment site. In the area where the experiment was installed, sugarcane was cultivated for 65 years with manual harvest and burning. In 2010, the plant adopted the mechanised harvesting system without burning, leaving the vegetal residue on the soil. Before planting, as practice of the planting, $70 \mathrm{tha}^{-1}$ of filter cake was applied in total area. Soil density analysis $\left(\mathrm{g} \mathrm{cm}^{-3}\right)$ was performed, which presented depths of $0-0.10 \mathrm{~m}$ and $0.10-0.60 \mathrm{~m}$, values of 1.33 and 1.30 , respectively, indicating that there was no physical impediment to root development. The soil was prepared by performing two harrowing treatments.

The experiment was carried out in randomised block design with six treatments: burned cane (where $100 \%$ of the straw was burned) and without burning where $0,25 \%\left(5 \mathrm{t} \mathrm{ha}^{-1}\right)$ and 50\% (10 t ha$\left.{ }^{1}\right)$ were left, $75 \%\left(15 \mathrm{t} \mathrm{ha}^{-1}\right)$ and 100\% $\left(20 \mathrm{t} \mathrm{ha}^{-1}\right)$ of straw on the soil, in four replications. Each plot consisted of 10 sugarcane lines, variety SP 801816 , $10 \mathrm{~m}$ long (10 rows $\mathrm{x} 10 \mathrm{~m})$, totalling 100 linear $\mathrm{m}$, spacing $1.50 \mathrm{~m}$ between rows. The six central rows with 9 linear $\mathrm{m}$ were used as a useful area for collecting the data, totalling 54 linear $\mathrm{m}$. 
Figure 1. Monthly water balance extract occurred during the third ratoon crop 2013/14. of sugarcane cv. SP801816 grown under different amounts of straw (\%) on the soil surface. DAH: days after harvesting.

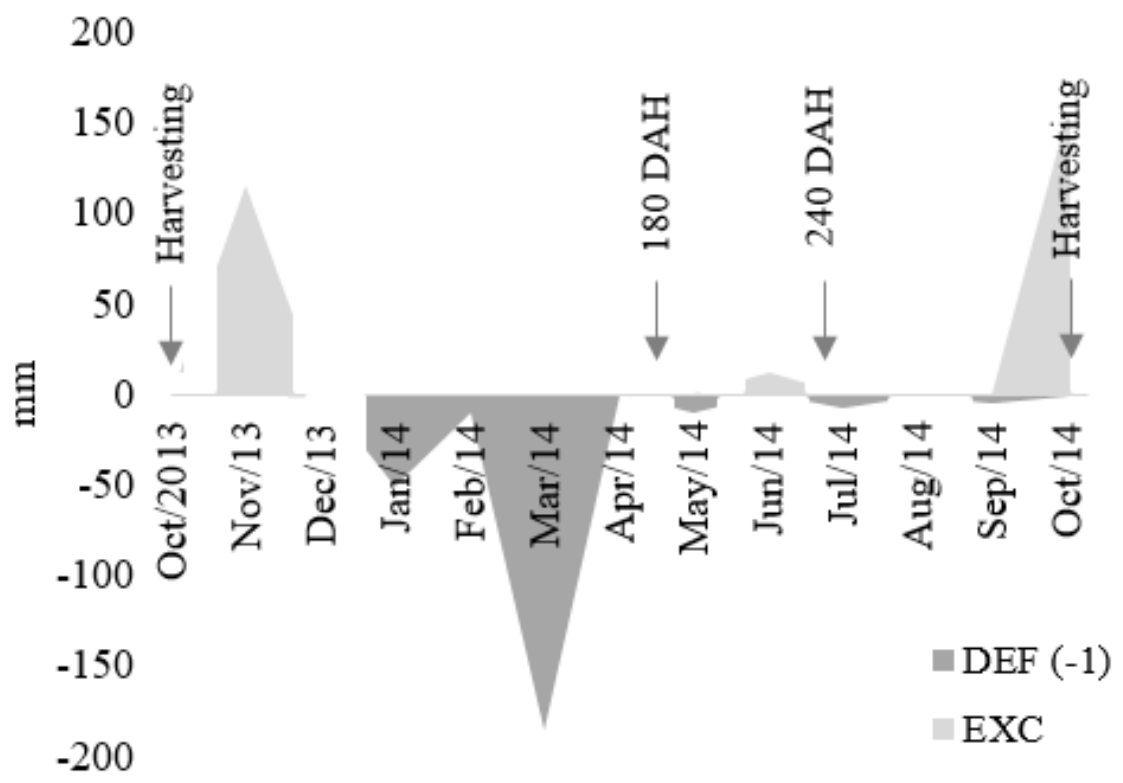

The implementation of the experiment was carried out in August 2010, and soon after planting the amount of straw corresponding to each treatment was added to the soil. In 2014, after four years of cultivation with the respective quantities of straw added or removed from the soil, the development and productivity analysis of the sugarcane was carried out. The following variables were evaluated in all stems contained in 2 linear m per plot: number of green leaves, leaf area (AF), leaf area index (LAI) number, length, diameter and fresh stem mass at $60,120,180,240$ days after cutting (DAC) and at harvest (370 DAC).

The average number of green leaves per tiller was determined by counting the fully expanded leaves, with a minimum $20 \%$ of green area, from the leaf +1 (HERMANN; CÂMARA, 1999). The leaf area (LA) was calculated with the help of a leaf area metre LiCor model LI 3100, by collecting the TVD leaf ('top visible dewlap') of each existing tiller, both in the 2 linear $\mathrm{m}$ and posteriorly, using Nassif et al. (2013) methodolgy. The leaf area per tiller was calculated using the equation $\mathrm{LAT}=\mathrm{LA} \times(\mathrm{N}+$
2), where: LA is the leaf area, $\mathrm{N}$ is the number of open green leaves and 2 is the weighting factor for leaves that are not yet fully expanded. The leaf area index (LAI), evaluated only on the first ratoon, was calculated using the equation: $\mathrm{LAI}=\mathrm{NTI} \times \mathrm{LA} / \mathrm{A}$, where: NTI is the number of tillers $\left(\mathrm{m}^{2}\right)$, LA is the leaf area per tiller $\left(\mathrm{m}^{2}\right)$ and $\mathrm{A}$ is the land area in $\mathrm{m}^{2}$ used for the evaluation.

For the determination of the number of stems per hectare, the stems contained in 2 linear $\mathrm{m}$ of each plot were counted. The mean length $(\mathrm{m})$ of the stems was obtained from the measurement of the soil level to the first visible auricle, classified as leaf +1 . The mean diameter of the stalks was obtained with the aid of a pachymeter measuring the middle third of the stalks. Productivity was obtained by weighing the stems in each evaluation period. Leaves and pointers were removed from all stalks prior to weighing.

The data was analysed using analysis of variance (ANOVA) and the means were compared via Tukey's test $(\mathrm{P}<0.05)$. 


\section{Results and Discussion}

There was a significant effect of the straw on the development of the third sugarcane ratoon. Regarding LAI, the highest LAI means occurred at 120 DAC (Figure 2), with subsequent decline. This behaviour was also observed by Oliveira et al. (2007) in the state of Paraná and Farias et al.
(2008) in the state of Paraíba. Sugarcane presents a phase in which there is greater growth. This differs according to the variety and, after this period of intense growth and competition of tillers, a decrease is also expected in the IAF, since the crop reduces the energy expenditure in the production of green leaves.

Figure 2. Leaf area index (LAI) of sugarcane cv. SP801816 grown under different amounts of straw $(0 ; 25 ; 50 ; 75$; $100 \%)$ on the soil surface and Burned sugarcane (B.S) on the third ratoon (2013/14 crop). Means followed by the same letter in each date of sampling are not significantly different by Tukey's test at $5 \%$ significance level.

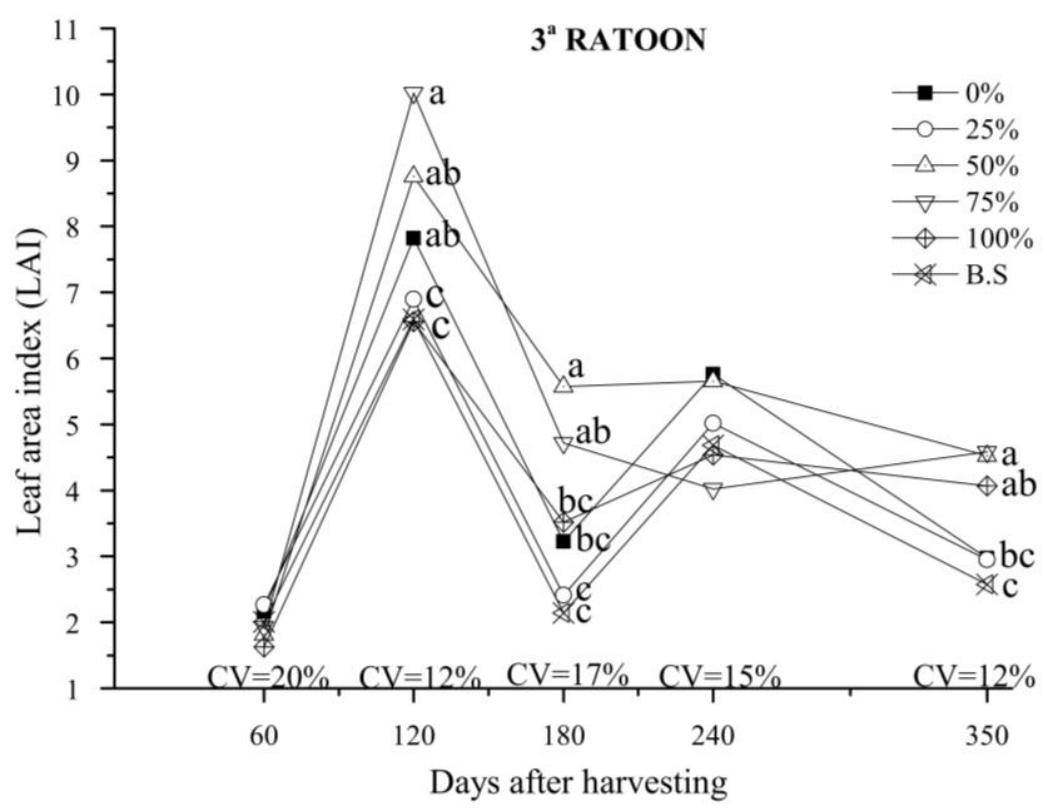

IAF decreases with the reduction of the number of tillers per linear metre. This, in turn, decreases with the decrease in soil moisture (FARIAS et al., 2008). Inman-Bamber (2004) confirms this information and adds that factors such as elevated temperatures in periods of water stress cause a decrease in leaf area as they accelerate the process of senescence of green leaves. In this cycle, where water deficit was observed throughout the cycle, except in November 2013 and June 2014, there was a straw effect on LAI at 120, 180 and 350 DAC. The treatments 50 and $75 \%$ of straw had the highest values until the end of the cycle, reaching $350 \mathrm{DAC}$ (4.52 and 4.58, respectively) in relation to treatments $0,25 \%$ of straw and burned sugarcane, which presented values of $2.97 ; 2.95$ and 2.52 , respectively. Silva and Pincelli (2010) report that the IAF is effective for evaluating the final yield, and higher values during the development cycle would be related to a higher final yield of stems. Inman-Bamber and Smith (2004) explain that after hydric deficit, when rehydration occurs, stomata can improve the water potential of the leaf but cannot fully recover, because the complexity of the stomata response will depend on the genotype and drought intensity, influencing the severity of the fall in production. Braunbeck and Magalhães (2010) point out that one of the main effects of straw on the soil is to increase the infiltration of water in the soil, and decrease the evaporation and the average 
temperature of the surface layer of the soil, thus allowing the maintenance of moisture due to the microclimate created.

There was a significant effect on stem diameter (Figure 3) in the 240 DAC period. The treatments 50 and $75 \%$ of straw provided a larger diameter of stalks $(2.85 \mathrm{~cm})$ in comparison to the cane burned and $25 \%$ of straw $(2.15$ and $2.10 \mathrm{~cm}$, respectively). At harvest, $100 \%$ straw had a larger diameter (2.90 $\mathrm{cm})$, differing only from 0 and $25 \%$ straw (2.72 and $2.65 \mathrm{~cm}$, respectively). Silva and Pincelli.
(2010) evaluated the production components of 80 sugarcane genotypes as indicators of drought tolerance in Neossolo. They verified that stem diameter is the most sensitive of the biometric indicators as it is one of the first parameters, and that the water deficit in the initial phase affects the cell division, reducing the diameter and weight of the stalks. This may explain the smaller diameter observed in treatments with uncovered soil (cane burned and the total removal of straw from soil).

Figure 3. Stem diameter of sugarcane cv. SP801816 grown under different amounts of straw $(0 ; 25 ; 50 ; 75 ; 100 \%)$ on the soil surface and Burned sugarcane (B.S) on the third ratoon (2013/14 crop). Means followed by the same letter in each date of sampling are not significantly different by Tukey's test at $5 \%$ significance level.

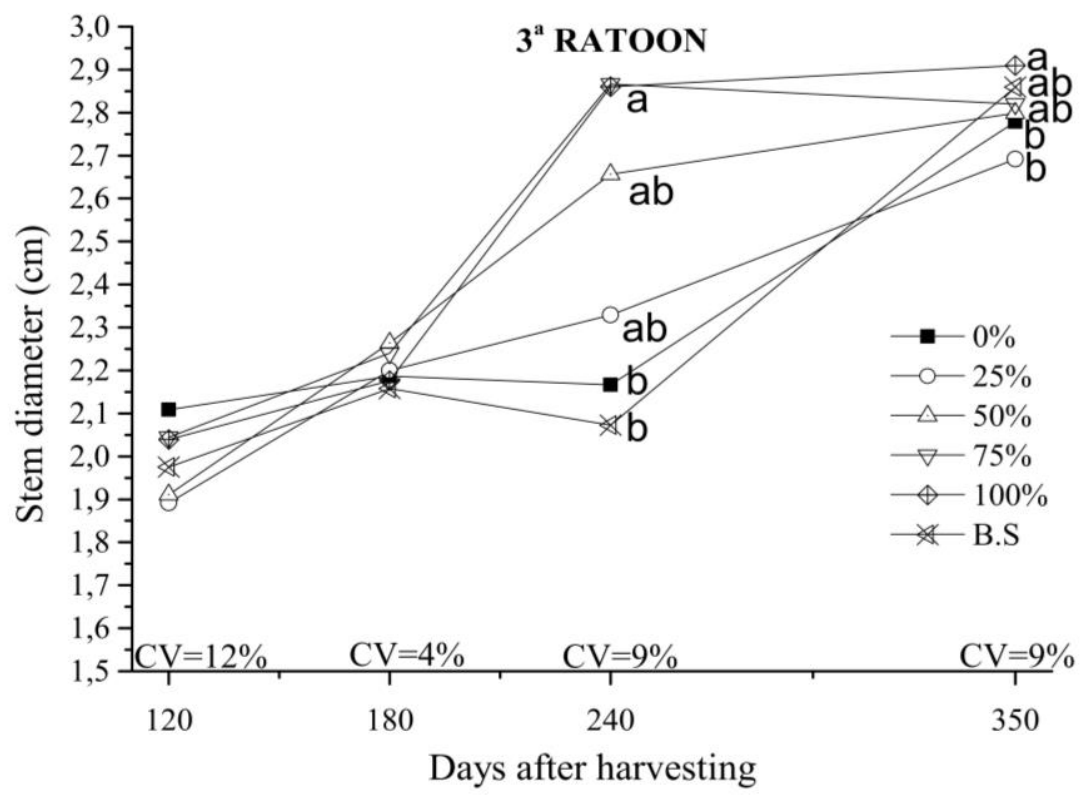

The mean length of stems (Figure 4) increased from the first to the last evaluation period. Similar results were found by Castro (1999). The stem length showed growth curves, as found in the literature. There was no significant effect of the treatments on the average length of stalks in any period evaluated.

There was a straw effect on the fresh stem mass $\left(\mathrm{Mg} \mathrm{ha}^{-1}\right)$ in the third ratoon at 60, 240 and 370 DAC (Figure 5). The treatments $50 \%$ and $75 \%$ of straw did not differ and provided the highest average of production in the whole cycle, in relation to the burned sugarcane 0 and $25 \%$ of straw. At the end of the cycle, at $370 \mathrm{DAC}\left(\mathrm{Mg} \mathrm{ha}^{-1}\right)$ treatments 50 and $75 \%$ of straw yielded the highest yields (119 and $122 \mathrm{Mg} \mathrm{ha}^{-1}$, respectively), with an average of $37 \%$ more compared to burned sugarcane and $0 \%$ of straw (74 and $77 \mathrm{Mg} \mathrm{ha}^{-1}$, respectively). Although it did not differ statistically, it represented $31 \%$ more than the $25 \%$ straw treatment on the soil. 
Figure 4. Stem length $(\mathrm{m})$ of sugarcane cv. SP801816 grown under different amounts of straw $(0 ; 25 ; 50 ; 75 ; 100 \%)$ on the soil surface and Burned sugarcane (B.S) on the third ratoon (2013/14 crop). Means followed by the same letter in each date of sampling are not significantly different by Tukey's test at 5\% significance level.

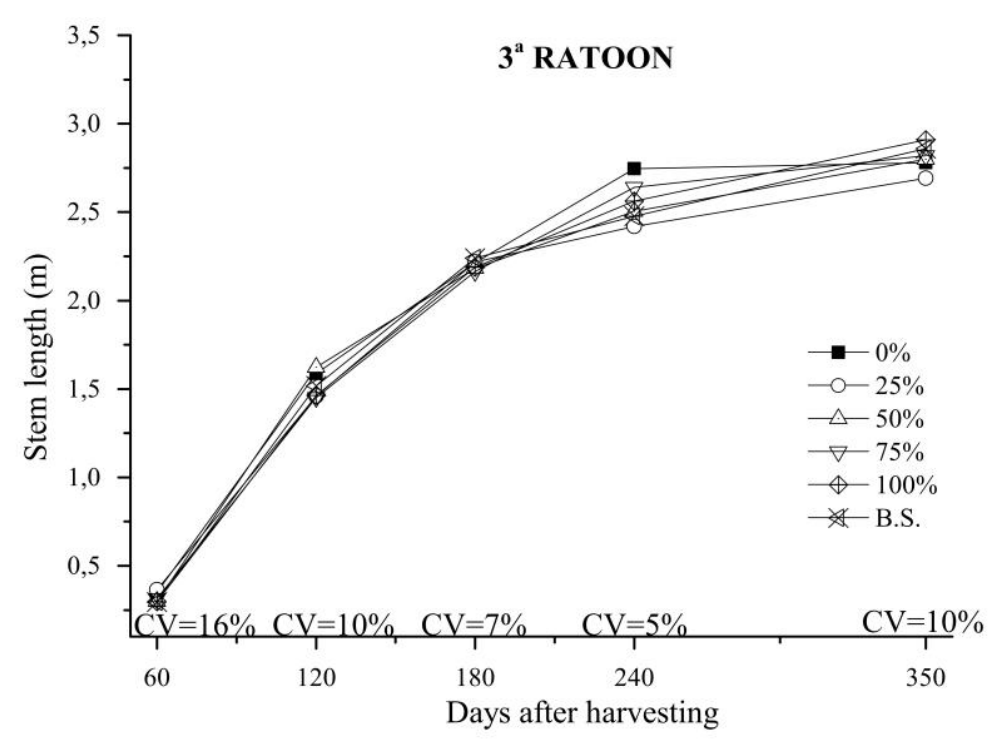

Figure 5. Productivity of sugarcane $\left(\mathrm{Mg} \mathrm{ha}^{-1}\right) \mathrm{cv}$. SP801816 grown under different amounts of straw $(0 ; 25 ; 50 ; 75$; $100 \%)$ on the soil surface and Burned sugarcane (B.S) on the third ratoon (2013/14 crop). Means followed by the same letter in each date of sampling are not significantly different by Tukey's test at $5 \%$ significance level.

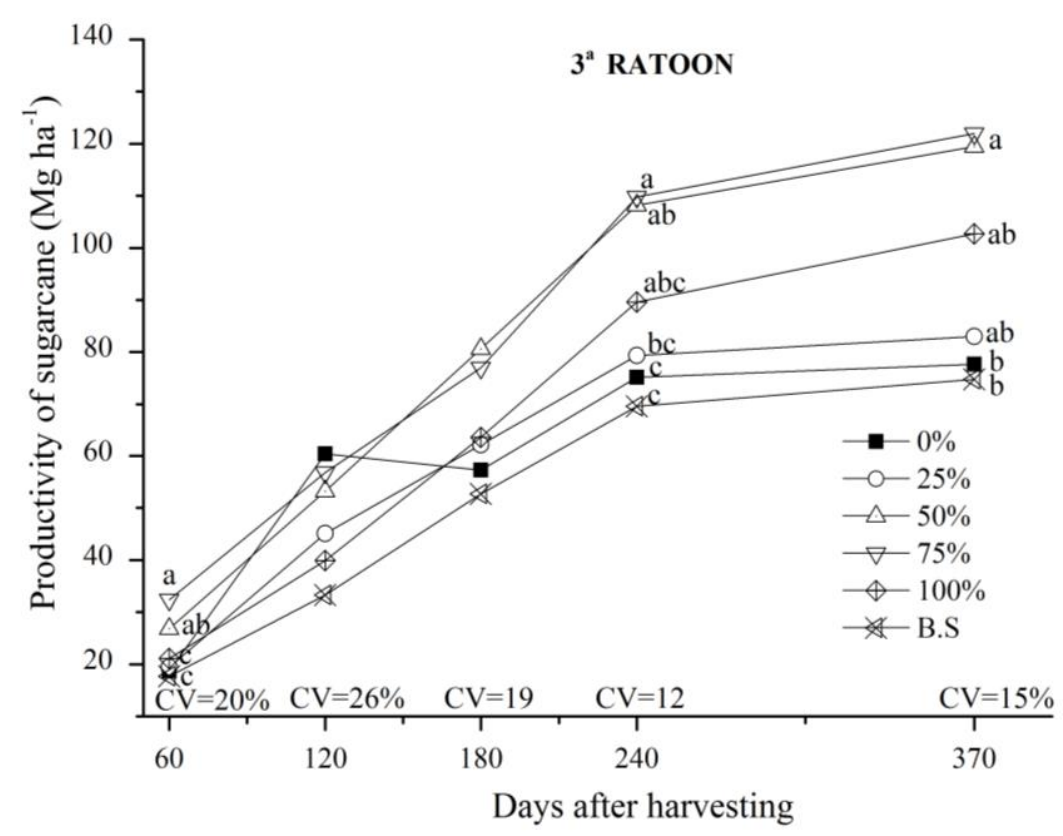

The results of the productivity of cane-plant and ratoon under different amounts of straw obtained by Aquino and Medina (2014) and Aquino et al. (2017), in the same experimental area of this research, corroborate the results of the present study. The authors verified that in the cycles where water deficiency occurred in the initial stages of the crop, treatments with 50 and $75 \%$ of straw increased the 
average productivity in the cane-plant cycle by $25 \%$ and in the cycle of the ratoon by $29 \%$, comparing with treatments with smaller amounts of straw.

These data show that the presence of straw has a significant influence on the cropping system, and may reflect the final productivity in the short-term, especially in periods of water deficiency, as in the present work. Another relevant result to highlight is that the practice of harvesting sugarcane with burning reduced productivity by $37 \%$ in periods of water deficiency. This is important information for choosing the harvest management technique to be adopted, especially for those states where there is no prohibition of burning and it is common to carry out the burning of sugarcane before harvesting.

It can be observed in the present study that under conditions of water deficit, the amount of $50 \%$ of straw was sufficient to promote improvements in crop productivity, and that, above this value, there were no statistically significant responses. The remainder residue could be used in the sectors of production of bioenergy, maximising the energy use coming from the crop, without prejudice to the sustainability of the cultivation system.

Considering that straw plays a fundamental role in soil erosion protection, which is one of the most damaging forms of degradation, by irreversibly reducing the productive capacity of the crops, the maintenance of straw on the surface is a very important management technique when the sustainability of the soil system is sought.

\section{Conclusion}

The straw on a soil surface provided a development benefit for the production of sugarcane. The management technique of burning the sugarcane, total removal of straw ( $0 \%$ of soil cover) or $75 \%$ of straw results in a lower leaf area index and stalk diameter, and a $37 \%$ decrease in final yield, in conditions of water deficiency. The maintenance of $50 \%$ straw is sufficient to favour the development and the majority production of sugarcane.

\section{Acknowledgements}

We thank PETROBRAS for financing this work, the Coordination of Higher Education Personnel (CAPES) (Scholarship Grants 6104 and 0704932), and the Bandeirantes Plant for the assignment of the experimental area and technical support in the ratings.

\section{References}

AQUINO, G. S.; MEDINA, C. C. Produtividade e índices biométricos e fisiológicos de cana-de-açúcar cultivada sob diferentes quantidades de palhada. Pesquisa Agropecuária Brasileira, Brasília, v. 49, n. 3, p. 173-180, 2014.

AQUINO, G. S.; MEDINA, C. C.; COSTA, D. C.; SHAHAB, M.; SANTIAGO, A. D. Sugarcane straw management and its impact on production and development of ratoons. Industrial Crops and Products, Oxford, v. 102, p. 58-64, 2017.

BALL-COELHO, B.; TIESSEN, H.; STEWART, J. W. B.; SALCEDO, I. H.; SAMPAIO, E. V. S. B. Residue management effects on sugarcane yield and soil properties in Northeastern Brazil. Agronomy Journal, Madison, v. 85, n. 5, p. 1004-1008, 1993.

BRAUNBECK, O. A.; MAGALHÃES, P. S. G. Avaliação tecnológica da mecanização da cana-de-açúcar. In: CORTEZ, L. A. B. Bioetanol de cana-de-açúcar. São Paulo: Blucher, 2010. p. 451-475.

CAMPOS, L. H. F. Sistemas de manejo da palhada influenciam acúmulo de biomassa e produtividade da cana-de-açúcar (var. RB855453). Acta Scientiarum. Agronomy, Maringá, v. 32, n. 2, p. 345-350, 2010.

CAMPOS, L. H. F.; CARVALHO, S. J. P.; CHRISTOFFOLETI, P. J.; FORTES, C.; SILVA, J. S. Crescimento e produtividade da cana-de-açúcar (Var. SP83-2847) submetida a três manejos da palhada. STAB - Açúcar, Álcool e Subprodutos, Piracicaba, v. 26, n. 6, p. 33-36, 2008.

CASTRO, P. R. C. Maturadores químicos em cana-deaçúcar. Saccharum, Piracicaba, v. 1, n. 4, p. 12-16, 1999.

CAVENAGHI, A. L.; ROSSI, C. V. S.; NEGRISOLI, E.; COSTA, E. A. D.; VELINI, E. D.; TOLEDO, R.E.B. 
Dinâmica do herbicida amicarbazone (Dinamic) aplicado sobre palha de cana-de-açúcar (Saccharum officinarum). Planta Daninha, Viçosa, v. 25, n. 4, p. 831-837, 2007.

CENTRO NACIONAL DAS INDÚSTRIAS DO SETOR SUCROENERGÉTICO E BIOCOMBUSTÍVEIS. CEISE. Usinas podem produzir novos $1.000 \mathrm{MW} / \mathrm{ano}$ de bioeletricidade. Disponível em: <http://www.ceisebr. com/site/index.php/conteudo/visualizar/usinas-podemproduzir-novos-1.000-mwano-de-bioeletricidade> . Acesso em: 28 maio 2016.

CHRISTOFFOLETI, P. J.; CARVALHO, S. J. P.; LÓPEZ-OVEJERO, R. F.; NICOLAI, M.; HIDALGO, E.; SILVA, J. E. Conservation of natural resources in Brazilian agriculture: implications on weed biology and management. Crop Protection, Guildford, v. 26, n. 3, p. 383-389, 2007.

COSTA, L. G.; MARIN, F. R.; NASSIF, D. S. P.; PINTO, H. M. S.; LOPES-ASSAD, M. L. R. C. Simulação do efeito do manejo da palha e do nitrogênio na produtividade da cana-de-açúcar. Revista Brasileira de Engenharia Agrícola e Ambiental, Campina Grande, v. 18, n. 5, p. 469-474, 2014.

EMPRESA BRASILEIRA DE PESQUISA AGROPECUÁRIA - EMBRAPA. Manual de métodos de análise de solo. 2. ed. rev. atual. Rio de Janeiro: EMBRAPA, 1997.212 p. (EMBRAPA-CNPS. Documentos, 1).

EMPRESA BRASILEIRA DE PESQUISA AGROPECUÁRIA - EMBRAPA. Sistema brasileiro de classificação de solos. 3. ed. Brasília: EMBRAPA, 2013. $353 \mathrm{p}$.

FARIAS, C. H. de A.; FERNANDES, P. D.; AZEVEDO, H. M.; DANTAS NETO, J. Índices de crescimento da cana-de-açúcar irrigada e de sequeiro no Estado da Paraíba. Revista Brasileira de Engenharia Agrícola e Ambiental, Campina Grande, v. 12, n. 4, p. 356-362, 2008.

GARCIA, J. F. G.; GRISOTO, E.; BOTELHO, P. S. M.; PARRA, J. R. P.; APPEZZATO-DA-GLÓRIA, B. Feeding site of the spittlebug Mahanarva imbriolata (STAL) (Hemíptera: Cercopidae) on sugarcane. Scientia Agrícola, Piracicaba, v. 64, n. 5, p. 555-557. 2007.

GUIMARÃES, E. R.; MUTTON, M. A.; MUTTON, M. J. R.; FERRO, M. I. T.; RAVANELI, G. C.; SILVA, J. A. Free proline accumulation in sugarcane under water restriction and spittlebug infestation. Scientia Agrícola, Piracicaba, v. 65, n. 6, p. 628-633, 2008.

HERMANN, E. R.; CÂMARA, G. M. S. Um método simples para estimar a área foliar de cana-de-açúcar. STAB - Açúcar, Álcool e Subprodutos, Piracicaba, v. 17, p. 32-34, 1999.
INMAN-BAMBER, N. G. Sugarcane water stress criteria for irrigation and drying off. Field Crops Research, Amsterdam, v. 89, n. 1, p. 107-122, 2004.

LIMA, M. A. P.; NATALENSE, A. P. P. Necessidade de pesquisa básica para cana e etanol. In: CORTEZ, L. A. B. Bioetanol de cana-de-açúcar. São Paulo: Blusher, 2010. p. $150-170$.

NASSIF, D. S.; MARIN, F. R.; COSTA, L. G. Padrões mínimos para coleta de dados experimentais para estudos sobre crescimento e desenvolvimento da cultura da cana-de-açúcar. Campinas: Embrapa Informática Agropecuária, 2013. 28 p. (Embrapa Informática Agropecuária, Documentos, 127).

OLIVEIRA, M. W.; BARBOSA, M. H. P.; MENDES, L. C.; DAMASCENO, C. D. Matéria seca e nutrientes na palhada de dez variedades de cana-de-açúcar. STABAçúcar, Álcool e Subprodutos, Piracicaba, v. 21, n. 3, p. 30-31, 2003.

OLIVEIRA, R. A.; DAROS, E.; ZAMBON, J. L. C.; WEBER, H.; IDO, O. T.; BESPALHOK-FILHO, J. C.; ZUFFELLATO-RIBAS, K. C.; SILVA, D. K. T. Área foliar em três cultivares de cana-de-açúcar e sua correlação com a produção de biomassa. Pesquisa Agropecuária Tropical, Goiânia, v. 37, n. 2, p. 71-76, 2007.

PAREDES JUNIOR, F. P.; PORTILHO, I. I. R.; MERCANTE, F. M. Microbiological attributes of the soil under cultivation of sugar cane with and without burning straw. Semina: Ciências Agrárias, Londrina, v. 36, n. 1, p. 151-164, 2015.

POTRICH, D. C.; MARCHETTI, M. E.; POTRICH, D. C.; ENSINAS, S. C.; SERRA, A. P.; SILVA, E. F.; SOUZA, N. H. Decomposition of sugarcane crop residues under different nitrogen rates. Semina: Ciências Agrárias, Londrina, v. 35, n. 4, p. 1751-1760, 2014.

RESENDE, A. S.; SANTOS, A.; XAVIER, R. P.; COELHO, C. H.; GONDIM, A.; OLIVEIRA, O. C.; ALVES, B. J. R.; BODDEY, R. M. Efeito da queima da palhada da cana-de-açúcar e de aplicações de vinhaça e adubo nitrogenado em características tecnológicas da cultura. Revista Brasileira de Ciência de Solo, Viçosa, v. 30, n. 6, p. 937-941, 2006.

SILVA, M. A.; PINCELLI, R. P. Alterações morfofisiológicas na cana-de-açúcar em resposta à deficiência hídrica. In: CRUSCIOL, C. A.C.; SILVA, M. A.; ROSSETO, R.; SORATTO, R. P. Tópicos em ecofisiologia da cana-de-açúcar. Botucatu: FEPAF Fundação de Estudos e Pesquisas Agrícolas e Florestais, 2010. p. 43-48. 
SOUZA, Z. M.; PAIXÃO, A. C. S.; PRADO, R. M.; CESARIN, L. G.; SOUZA, S. R. Manejo de palhada de cana colhida sem queima, produtividade do canavial e qualidade do caldo. Ciência Rural, Santa Maria, v. 35, n. 5, p. 1062-1068, 2005.

TAVARES, O. C. H.; LIMA, E.; ZONTA, E. Crescimento e produtividade da cana-planta cultivada em diferentes sistemas de preparo do solo e de colheita. Acta Scientiarum. Agronomy, Maringá, v. 32, n. 1, p. 61-68, 2010.

THORNTHWAITE, C. W.; MATHER, J. R. The water balance. Publications in climatology. New Jersey: Drexel Institute of Technology, 1955. 104 p.
UNIÃO DA INDÚSTRIA DA CANA-DE-AÇÚCAR UNICA. Qual a expansão prevista para o cultivo da canade-açúcar no Brasil nos próximos anos? São Paulo, 2012. Disponível em: <http://www.unica.com.br /FAQ/>. Acesso em: 28 maio 2015.

VALIM, W. C.; PANACHUKI, E.; PAVEI, D. S.; ALVES SOBRINHO, T.; ALMEIDA, W. S. Effect of sugarcane waste in the control of interrill erosion. Semina: Ciências Agrárias, Londrina, v. 37, n. 3, p. 1155-1164, 2016. 